
\title{
R Reserach S Suare \\ Clinical features and aetiology of newly diagnosed adrenal insufficiency: A single-centre retrospective cross-sectional study in Japan.
}

\section{Makoto Misaki}

National Hospital Organization Tochigi Medical Center

Junpei Komagamine ( $\square$ junpei0919@yahoo.co.jp )

National Hospital Organization Tochigi Medical Center https://orcid.org/0000-0002-5899-4760

\section{Research Article}

Keywords: adrenal crisis, adrenal insufficiency, ACTH deficiency

Posted Date: June 5th, 2020

DOI: https://doi.org/10.21203/rs.3.rs-33309/v1

License: (c) (1) This work is licensed under a Creative Commons Attribution 4.0 International License.

Read Full License 


\section{Abstract}

Background: Central adrenal insufficiency (Al) has been reported to be twice as common as primary Al outside Japan. The most common causes of central Al are drugs and pituitary tumours. However, given the significant differences in the incidence rates of Addison's disease and isolated ACTH deficiency between Japan and other countries, the most common causes of Al in Japan may differ from those in other countries. Furthermore, few studies have focused on the clinical features of newly diagnosed central Al.

Methods: A retrospective single-centre observational study using electronic medical records from April 2012 to December 2019 was conducted. The main outcome was the proportion of cases of central Al among all cases of newly diagnosed Al. We also investigated the clinical features and common causes of central Al. Only patients with Al confirmed with hormone tests were included. Patients with Al who were asymptomatic or diagnosed clinically without hormone test confirmation were excluded. Based on hormone tests and the clinical diagnosis, Al was classified into primary and central Al.

Results: A total of 34 patients were eligible. The mean patient age was 76.3 years, 11 (32.4\%) were women, and 11 (32.4\%) were former or current users of glucocorticoids for non-endocrine diseases. Of the 34 patients with newly diagnosed Al, all (100.0\%) had central Al. The most common cause of central Al was glucocorticoids $(n=11,32.4 \%)$, followed by central hypoadrenalism of unknown causes $(n=9$, $26.5 \%)$, idiopathic isolated ACTH deficiency $(n=6,17.7 \%)$, and pituitary tumours $(n=5,14.7 \%)$. For the 34 patients with central Al, the mean time to receive a correct diagnosis from the onset was 6.2 months. The most common symptoms at diagnosis were anorexia $(n=26,76.5 \%)$, fatigue $(n=23,67.6 \%)$, asthenia $(n=22,64.7 \%)$ and nausea or vomiting $(n=19,55.9 \%)$.

Conclusions: Primary Al is rare in Japan. The most common cause of newly diagnosed central Al is glucocorticoid use. Pituitary tumours may be a less common cause of central Al in Japan than in other countries.

\section{Background}

Adrenal insufficiency (Al) is a life-threatening disorderthatresults from adrenal failure due to impairment ofthehypothalamic-pituitary-adrenal axis [1]. Al is uncommon, butadelay in its diagnosis leads to a fatal event. Nonetheless,delaysin the diagnosis of Al are common [2,3]. To preventdiagnosticdelay, it is important to know the common causes andpresentingfeatures of Al.

Al is classified as primary and central (including secondaryandtertiary) based on the underlying mechanism [1]. Recent andpastreviews reported that the prevalence and incidence of centralAlare estimated to be approximately twice as frequent as thoseofprimary Al [4], and the most common causes of central Alareglucocorticoids and pituitary tumours [1,4-7]. However, most ofthepast studies cited in those reviews investigated theepidemiologyof primary Al [2,8-14] and central AI [10,1518]separately.Moreover, all past studies investigating theepidemiology ofcentral Al targeted patients with 
hypopituitarism[15,17,18] orpituitary adenoma [16] rather than patients withhypoadrenalism. Inaddition, glucocorticoid-induced Al, which isconsidered to be themost common type of central Al [1,4-7,19-21],was not included inthose studies [2,8-18]. Thus, no studies havefocused on theaetiology of newly diagnosed Al includingglucocorticoid-induced Al[4]. Furthermore, given that past studiessuggested that there aresubstantial differences in the prevalencerates of Addison'sdisease $[11,13,22,23]$ and idiopathic isolatedadrenocorticotropichormone (ACTH) deficiency $[24,25]$ between Japanand othercountries, it is possible that the frequency of causes ofAl inJapan is different from that in other countries.

Inclinicalpractice, when $\mathrm{Al}$ is diagnosed, whether $\mathrm{Al}$ is caused bydiseases ofthe adrenal gland (primary) or pituitary gland orhypothalamus(central) is subsequently investigated $[1,26,27]$. Therefore,knowing the frequency of causes of newly diagnosed Alisimportant.

With regard to the clinical features of Al, most of thereferences cited in the reviews $[1,7,19]$ andendocrinologytextbooks [20] are old studies published more than twodecades ago[28-31]. Furthermore, few studies have focused on thefeatures of central Al at presentation $[4,29]$ because most paststudiesinvestigated only clinical features of central Al due tospecificaetiologies [24,30,32-35], such as pituitary apoplexy[34,35] oridiopathic isolated ACTH deficiency $[24,30,32]$. Inaddition, nostudies have been conducted to investigate the clinicalfeatures ofglucocorticoid-induced Al because nearly all studiesregardingglucocorticoid-induced Al targeted asymptomatic ratherthansymptomatic biochemical Al induced by glucocorticoiduse[21,36-39]. Therefore, more studies are needed to investigatethefeatures at presentation, particularly for central Al.

Thus, the aim of our study was to determine the frequencyofcauses of newly diagnosed Al and investigate the featuresofcentral Al at presentation. We investigated the proportion ofcasesof central Al among all newly diagnosed Al cases andevaluatedwhether glucocorticoid use for non-endocrine diseases andpituitarytumours are the most common causes of central Al in Japan.

\section{Methods}

\section{Study setting and design}

To investigate the aetiology of newly diagnosed Al, weconducteda retrospective single-centre crosssectional study usingmedicalelectronic records. Our hospital is a 350-bed communitygeneralhospital, and it is one of the two largest hospitals,coveringapproximately 0.5 million people in Utsunomiya,Japan.

\section{Inclusion and exclusion criteria}

Patients who were 18 years old or older and who werenewlydiagnosed with Al and started hormone replacement therapyduringthe study period were included. We included only patients whometall the following criteria: (1) the presence of somesymptomsconsistent with $\mathrm{Al}$; (2) hormone test confirmation of Al;and (3)started glucocorticoid replacement therapy. Patients with Althatwas diagnosed at another hospital during the study periodwereexcluded. 


\section{Definitions}

Based on past reviews $[1,40,41]$ and guidelines [42], apatientswas considered to have Al that was confirmed by a hormonetest ifany of the following criteria were satisfied: (1) a serumcortisollevel less than $5 \mu \mathrm{g}$ per decilitre in the morning (from8:00 A.M.to 9:00 A.M.) or (2) a serum cortisol level from 5 to $18 \mu \mathrm{g}$ perdecilitre in the morning and a peak serum cortisol level lessthan $18 \mu \mathrm{g}$ per decilitre at 30 minutes

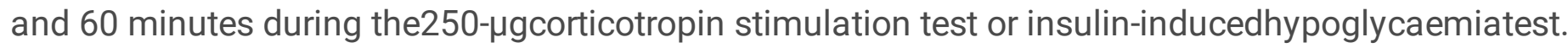
Central Al was differentiated from primary Al bymeans of themorning plasma ACTH level. Based on past studies andreviews[26,42,43], primary AI was defined as Al with a plasma ACTHlevelgreater than 2 times the upper limit of the referencerange.Otherwise, Al was classified as central Al. There is noconsensusfor the definition of idiopathic isolated ACTH deficiency.Based onpast cases and reviews [24,32,44,45], idiopathic isolatedACTHdeficiency was identified if the following criteria were allmet:(1) central Al was confirmed by hormone tests; (2) no signsorlaboratory findings suggested deficiencies in otheranteriorpituitary hormones; and (3) no organic pituitary lesionwasobserved on brain imaging.

\section{Screening anddatacollection}

We identified patients with Al from the database of ourhospital.All patients who were diagnosed with Al in outpatient andinpatientsettings from April 2012 to December 2019 were identifiedusing thelnternational Statistical Classification of Diseases andRelatedHealth Problems codes (more detailed information is shownin thesupplementary file; Table S1). An initial search identified131 patients during the study period.

Of those, 47 patients werenewlydiagnosed with Al and treated by hormone replacement.Afterexcluding 12 patients who were treated by hormonereplacementwithout confirmation by hormone tests, a total of 34patients wereincluded in the final analysis (Figure).

Physicians (JK, MM) independently reviewed the electronicmedicalrecords and retrieved information on patient age, sex, pastmedicalhistory, medication use, vital signs, time to a correctdiagnosisfrom symptom onset, symptoms, physical findings,laboratoryfindings, imaging results, aetiology of Al, treatmentfor $\mathrm{Al}$, andprognosis. Discrepancies between the two investigatorswere resolvedby discussion. The last followup date forinformation on prognosiswas 17 December 2019.

\section{Outcome measures}

The primary outcome was the proportion of patients whowerediagnosed with central Al among all patients newly diagnosedwithAl. The secondary outcomes were the proportions of patientswhowere diagnosed with glucocorticoid-induced $\mathrm{Al}$ and Al duetopituitary tumours among those newly diagnosed with central Al.Wealso investigated the frequency of presenting symptoms andclinicalfindings of central Al stratified by whether the Al was duetoglucocorticoids or other causes.

\section{Statistical analysis}

The baseline characteristics of the study populationarepresented as descriptive statistics. The comparisons ofclinicalfeatures between patients who were diagnosedwithglucocorticoid-induced Al and 
central Al due to other causeswereperformed by using Fisher's exact test for categoricalvariablesand Student's t-test for continuous variables. Based ontheanecdotal evidence that most physicians candiagnoseglucocorticoid-induced Al with few tests needed [46], wetested thehypothesis of whether the time to correct diagnosis fromonset isfaster for glucocorticoid-induced Al than for central Aldue toother causes. The level of statistical significance was setat 5\%.Stata version 15 (LightStone, Tokyo, Japan) or Excelstatisticalsoftware package version 2.11 (Bellcurve for Excel;Social SurveyResearch Information Co., Ltd., Tokyo, Japan) wereused for theseanalyses.

\section{Results}

The baseline characteristics of the 34 patients who werenewlydiagnosed with Al are shown in Table 1 (detailed informationisshown in the supplementary file; Table S2). The mean age was76.3years old (SD 14.1), 11 (32.4\%) were women, and 11 (32.4\%)werecurrent or former glucocorticoid users for nonendocrinediseases. With regard to their past medical history, 7 (20.6\%) hadarheumatological disease, 1 $(2.9 \%)$ had a pituitary tumour, and $1(2.9 \%)$ had autoimmune thyroid disease. No patients had apasthistory of Cushing's disease, acromegaly, or type 1 diabetesmellitus. The mean morning serum cortisol and plasmaACTHconcentrations were 4.1 micrograms per decilitre (SD 3.4) and15.0picograms per millilitre (SD 10.7), respectively (moredetailedinformation is shown in the supplementary file; Table S3).Of the34 patients, all (100\%) were classified as having central Al,andthere were no patients who were classified as having primaryAlduring the study period. The most common cause of central Alwasglucocorticoid use (n $=11,32.4 \%)$, followed by unspecifiedorunknown cause $(n=9,26.5 \%)$, idiopathic isolated ACTHdeficiency $(n=6,17.7 \%)$, and pituitary tumour $(n=5,14.7 \%)$. Ofthe 5 patients with pituitary tumours, 4 had non-functioningpituitaryadenomas, and one had a Rathke's cleft cyst.

Among the 34 patients with central Al, the mean time to acorrectdiagnosis from onset was 6.2 months (SD 10.2). In total, 15(44.1\%)and 28 (82.4\%) were diagnosed correctly within one monthand oneyear from onset, respectively. The time to a correctdiagnosis fromonset for central Al due to other causes wassignificantly longerthan that for glucocorticoid-induced $\mathrm{Al}(p=0.03)$ (Table2). The most common symptom of centralAl at diagnosis was anorexia $(n=26,76.5 \%)$, followed by fatigueor malaise $(n=23$, $67.6 \%)$,asthenia $(n=22,64.7 \%)$ and nausea orvomiting $(n=19,55.9 \%)$.Although fatigue or malaise $(p$ $=0.001)$ and asthenia $(p=0.01)$ were significantly morecommonly seen inpatients with glucocorticoidinduced Al than inpatients withcentral Al due to other causes, there were nosignificantdifferences in other symptoms between the two groups.Regarding thelaboratory findings of the 34 patients with centralAl, the meanserum concentrations of sodium, potassium, and glucosewere 134milliequivalents per litre (SD 12), 4.3 milliequivalentsper litre(SD 0.8), and 110 milligrams per decilitre (SD 62),respectively.While the serum concentration of potassium wassignificantly lowerin patients with glucocorticoid-induced Alsthan those with centralAI due to other causes $(p=0.04)$,the serum concentrationof glucose was higher in patients withglucocorticoid-induced Alsthan those with central Al due to othercauses $(p=0.003)$.Compared with patients withglucocorticoid-induced Al, patients withcentral Al due to othercauses more often had hyponatremia due tosyndrome of inappropriatesecretion of antidiuretic hormone (SIADH) $(0 \%$ versus $39.1 \%, p=0.02)$. 
Of the 34 patients with central Al, 34 (100.0\%), 4 (11.8\%), and1(2.9\%) initiated treatment with hormone replacementforglucocorticoids, thyroid hormone, and desmopressin,respectively,after diagnosis. During the mean follow-up time of 12.9 months, onecardiovascular event $(2.9 \%)$ and five deaths (14.7\%)occurred.

\section{Discussion}

Our findings show that the frequency of central $\mathrm{Al}$ is muchhigherthan that of primary $\mathrm{Al}$ in a Japanese hospital. Given thatprimaryAl and central Al occur in a 1:2 ratio based on paststudiesconducted outside Japan [4], it is surprising that no casesofprimary Al were diagnosed while more than 20 cases of centralAlwere diagnosed during the same period in this study.Nonetheless,this result may be supported by past studies reportingthatAddison's disease is much less common in Japan than inothercountries $[11,13,22,23]$.

In the present study, the most common cause of newlydiagnosedcentral Al was glucocorticoids. This result supportsindirectevidence $[1,4-7,19-21,36-39]$ that the most common cause ofcentralAl is probably glucocorticoids because the prevalence ratesofchronic glucocorticoid use and biochemical Al amongglucocorticoidusers are high [21,36-39]. However, Al due topituitary tumoursaccounted for less than one-fourth of all cases ofnewly diagnosedcentral Al excluding glucocorticoid-induced Al inthis study. Thisresult is not consistent with the results of paststudies thatreported that more than two-thirds of central Alexcludingglucocorticoid-induced AI was caused by pituitarytumours $[3,7,15,17,18]$. Given that these past studies $[3,15,17,18]$ wereconducted outside Japan and idiopathic isolated ACTH deficiencymaybe more common in Japan than in other countries [24,25],ourfinding suggests that pituitary tumours are a relativelylesscommon cause of central Al in Japan. However, our studyhaslimitations due to the small sample size and single-centrestudydesign. Furthermore, given that few studies have focused ontheaetiology of newly diagnosed central Al and most paststudiestargeted hypopituitarism rather than hypoadrenalism[15,17,18],further studies are needed to investigate the aetiologyof newlydiagnosed central Al in Japan and other countries.

In the present study, approximately $20 \%$ of all newly diagnosedAlwas diagnosed more than one year after onset. Our findingisconsistent with that of past studies showing that diagnosticdelayof $\mathrm{Al}$ is common $[2,3]$. Moreover, the time to correct diagnosisfromthe onset was significantly shorter for patientswithglucocorticoid-induced Al than for those with central Al duetoother causes in this study. This result supports anecdotalevidence $[41,46]$ that glucocorticoid-induced $\mathrm{Al}$ is easier todiagnose thancentral Al due to other causes. To improve thisdiagnostic delay,further studies investigating associated factorsare warranted.

With regard to the features of central Al atpresentation,excluding glucocorticoid-induced Al, our findings areconsistentwith those of past studies [3,29], showing that the mostcommonsymptoms are fatigue, asthenia, and gastrointestinalsymptoms; itis noteworthy that one [3] of the two previous studieshad recallbias because the survey was administered a long timeafter thediagnosis was made. However, abdominal pain and diarrhoeaasgastrointestinal symptoms were relatively less common inthisstudy, 
although other gastrointestinal symptoms were common. Thiswas also consistent with the findings of past studies thatshowedthat abdominal pain and diarrhoea were less common inpatients withcentral Al than in those with primary AI [3,29]. Inthe presentstudy, a substantial proportion of patients with centralAI hadhypoglycaemic episodes and hyponatremia before diagnosis. Theseresults are also consistent with the results of paststudiesinvestigating the clinical features of isolated ACTHdeficiency[24,30,32] or central Al [29].

To the best of our knowledge, this study was the firsttoinvestigate the features of glucocorticoid-induced Al at thetimeof presentation because past studies on glucocorticoid-inducedAltargeted asymptomatic rather than asymptomatic Al inglucocorticoidusers [21,36-39]. There was no difference in clinicalfeaturesbetween glucocorticoid-induced Al and central Al due toothercauses. However, fatigue and asthenia were less common inpatientswith glucocorticoid-induced Al than those with central Aldue toother causes. Moreover, hypoglycaemic episodes andhyponatremiawere also less frequent in patients withglucocorticoid-induced Althan in those with central Al due to othercauses. Given that thetime to correct diagnosis was shorter inpatients withglucocorticoid-induced Al than in those with centralAl of othercauses, these symptoms and findings may develop if Al isnottreated promptly after onset.

\section{Strengths and weaknesses}

To the best of our knowledge, this was the first studytodetermine the aetiology of newly diagnosed Al and investigatetheclinical features of central Al, includingglucocorticoid-inducedAl. To avoid including diseases other thanAl, we included onlycases of Al that were confirmed by hormonetests. Moreover, becausenone of the hormone tests, including theinsulin tolerance test,correctly classifies all patients with Al[ $[1,7,40]$, only patientswho were symptomatic and treated by hormonereplacement wereincluded.

However, our findings should be interpreted cautiously.First,our study was a retrospective observational study. Therefore,thedata extracted for use in this study might not beaccurate.Moreover, Al that was not coded by the attendingphysicians wasmissed in this study. Second, we excluded Al that wasdiagnosedclinically without confirmation by hormone tests. However,none ofthe 13 excluded patients who had Al treated by hormonereplacementtherapy without confirmation by hormone tests hadprimary Al.Furthermore, even if the 5 excluded patients with Al whoweretreated by hormone replacement therapy after surgery forpituitarytumours who lacked Al symptoms and confirmation fromhormone testswere included in this study, Al due to pituitarytumours accountedfor less than half of the cases of central Al.Third, our study wasa single-centre study with a small sample size.Therefore, furthermulticentre studies should be performed toinvestigate theaetiology of newly diagnosed Al. Fourth, the use ofunprescribedcorticosteroid-like agents [41] is not routinelyassessed in ourhospital. Moreover, the assessment of the effect oftopical andintra-articular glucocorticoid use on Al might beinsufficient.Therefore, the frequency of drug-induced Al mightbeunderestimated. Fifth, given the limited sensitivity of the $250-\mu$ gcorticotropin stimulation test for central Al, particularlyin theearly phase after onset $[47,48]$, the frequency of central Almighthave been underestimated. Sixth, pituitary hormones otherthancorticotropin were not routinely investigated by laboratorytestswithout clinical suspicion of 
deficiency. Therefore,deficienciesof other pituitary hormones, which could affect thesymptoms andsigns of patients, might have beenunderestimated.

\section{Implications for clinical practice}

In the present study, primary Al was rare and pituitarytumoursaccount for less than one-fourth of the cases of central Al.In areview article published 80 years ago, Sheehan stated that thetruetype of central Al due to tumours is rare [33]. Ourfindingssuggest that pituitary tumours may not be common causes ofcentralAl in Japan, unlike in other countries. However, given thatfewstudies have focused on the aetiology of newly diagnosed centralAI[4] and that most past studies conducted in countries outsideofJapan [15-18] targeted hypopituitarism and nothypoadrenalism,further studies are warranted to investigate theaetiology of newlydiagnosed central Al in Japan and othercountries.

\section{Conclusions}

Primary Al is rare in Japan. The most common cause ofnewlydiagnosed central Al is glucocorticoid use, and the proportionofpatients with Al caused by pituitary tumours may be smallerinJapan than in other countries. The most common symptoms of centralAl are fatigue, asthenia, and gastrointestinal symptoms,andhypoglycaemic episodes and hyponatremia are sometimesconcomitant.Further studies investigating the aetiology of newlydiagnosed Aland evaluating the clinical features of central $\mathrm{Al}$ areneeded.

\section{Abbreviations}

Al: adrenal insufficiency; ACTH: adrenocorticotropic hormone;SD:standard deviation; SIADH: syndrome of inappropriate secretionofantidiuretic hormone.

\section{Declarations}

\section{Acknowledgements}

None.

\section{Funding}

None.

\section{Availability of data and materials}

All data generated or analysed during this study are includedinthis manuscript and the additional file.

\section{Authors' contributors}


$\mathrm{JK}$ and $\mathrm{MM}$ conceived of and designed this study. JK wrotetheprotocol for this study. JK and MM collected the data. JKanalysedand guarantee the data. JK wrote the draft of themanuscript. Allauthors contributed to the revision of themanuscript and read andapproved the final manuscript.

\section{Ethics approval and consent to participate}

The protocol of this research was approved by the MedicalEthicalCommittee of the National Hospital Organization TochigiMedicalCentre (No. 2019-15). We conducted the research inaccordance withthe Ethical Guidelines for Epidemiological Researchin Japan and theDeclaration of Helsinki. The need for individualinformed consentwas formally waived by the Medical EthicsCommittee of the NationalHospital Organization Tochigi MedicalCentre because we collecteddeidentified data without contactingthe patients. However, per theJapanese Ethical Guidelines, wedisplayed an opt-out statement inthe waiting room and webpage ofthe hospital to inform patientsabout the study and provide theopportunity for patients to refuseto allow the use of theirdata.

\section{Consent for publication}

Not applicable.

\section{Competing interests}

None of the authors have financial relationships withanyorganizations that might have an interest in this submitted workorother relationships or activities that could appear tohaveinfluenced the submitted work.

\section{References}

1. Charmandari E, Nicolaides NC, Chrousos GP,Adrenalinsufficiency. Lancet2014;383(9935):215267.doi:10.1016/S0140-6736(13)61684-0.

2. Erichsen MM, Løvås K, Skinningsrud B, et al.Clinical,immunological, and genetic features of autoimmune primaryadrenalinsufficiency: observations from a Norwegian registry.JClinEndocrinol Metab2009;94(12):4882-90.doi:10.1210/jc.2009-1368.

3. Bleicken B, Hahner S, Ventz M, Quinkler M. Delayed diagnosisofadrenal insufficiency is common: a cross-sectional study in216patients. Am J Med Sci2010;339(6):525-

31.doi:10.1097/MAJ.0b013e3181db6b7a.

4. Chabre O, Goichot B, Zenaty D, Bertherat J. Group1:Epidemiology of primary and secondary adrenalinsufficiency:prevalence and incidence, acute adrenalinsufficiency, long-termmorbidity and mortality. Ann Endocrinol(Paris)2017;78:490-4. doi:10.1016/j.ando.2017.10.010.

5. Proust-Lemoine E, Reynaud R, Delemer B, TabarinA,Samara-Boustani D. Group 3: Strategies for identifying the causeofadrenal insufficiency: diagnostic algorithms. AnnEndocrinol(Paris)2017;78(6):512-24.doi:10.1016/j.ando.2017.10.006. 
6. Crowley RK, Argese N, Tomlinson JW, Stewart PM.Centralhypoadrenalism. J Clin EndocrinolMetab2014;99(11):4027-36. doi:10.1210/jc.2014-2476.

7. Arit W, Allolio B. Adrenal insufficiency.Lancet2003;361(9372):1881-93.doi:10.1016/S01406736(03)13492-7.

8. Kong MF, Jeffcoate W. Eighty-six cases of Addison'sdisease. Clin Endocrinol(Oxf)1994;41:75761.doi:10.1111/j.1365-2265.1994.tb0290.x.

9. Willis AC, Vince FP. The prevalence of Addison's diseaseinCoventry, UK. Postgrad Med J1997;73(859):286-8.doi:10.1136/pgmj.73.859.286.

10. Laureti S, Vecchi L, Santeusanio F, Falorni A. Is theprevalenceof Addison's disease underestimated? J ClinEndocrinolMetab 1999;84(5):1762.doi:10.1210/jcem.84.5.5677-7.

11. Løvås K, Husebye ES. High prevalence and increasing incidenceofAddison's disease in western Norway. ClinEndocrinol(Oxf)2002;56(6):787-91.doi:10.1046/j.1365-2265.2002.t01-1-01552.x.

12. Betterle C, Scarpa R, Garelli S, et al. Addison's disease:asurvey on 633 patients in Padova. Eur JEndocrino/2013;169(6):773-84. doi:10.1530/EJE-13-0528.

13. Björnsdottir S, Sundström A, Ludvigsson JF, Blomqvist P,KämpeO, Bensing S. Drug prescription patterns in patients withAddison'sdisease: a Swedish population based cohort study. JClinEndocrinol Metab2013;98(5):2009-18.doi:10.1210/jc.2012-3561.

14. Meyer G, Neumann K, Badenhoop K, Linder R. Increasingprevalenceof Addison's disease in German females: health insurancedata2008-2012. Eur J Endocrino/2014;170(3):367-73.doi:10.1530/EJE-130756.

15. Bates AS, Hoff WV, Jones PJ, Clayton RN. The effectofhypopituitarism on life expectancy. $J$ ClinEndocrinolMetab 1996;81(3):1169-72.doi:10.1210/jcem.81.3.8772595.

16. Nilsson B, Gustavsson-Kadaka E, Bengtsson BÅ, JonssonB.Pituitary adenomas in Sweden between 1958 and 1991:incidence,survival, and mortality. J Clin EndocrinolMetab2000;85(4):1420-5. doi:10.1210/jcem.85.4.6498.

17. Regal M, Páramo C, Sierra JM, García-Mayor RV. Prevalenceandincidence of hypopituitarism in an adult Caucasian populationinnorthwestern Spain. Clin Endocrinol(Oxf)2001;55(6):73540.doi:10.1046/j.1365-2265.2001.01406.x.

18. Tomlinson JW, Holden N, Hillis RK, et al. Associationbetweenpremature mortality and hypopituitarism. West MidlandsProspectiveHypopituitary Study Group. Lancet2001;357(9254):42531.doi:10.1016/s0140-6736(00)04006-x.

19. Oelkers W. Adrenal insufficiency. N Engl JMed1996;335(16):1206-12. doi:10.1056/NEJM199610173351607.

20. Newell-Price JDC, Auchus RJ. Chapter 15: The adrenalcortex.Glucocorticoid deficiency. Williams TextbookofEndocrinology. 14 ${ }^{\text {th }}$ Philadelphia:Elsevier;2020:517-27.

21. Broersen LH, Pereira AM, Jørgensen JO, Dekkers OM.Adrenallnsufficiency in corticosteroids use: systematic reviewandmeta-analysis. J Clin EndocrinolMetab2015;100(6):2171-80. 
doi:10.1210/jc.2015-1218.

22. Nomura K, Demura H, Saruta T. Addison's disease inJapan:characteristics and changes revealed in a nationwidesurvey.Intern Med1994;33(10):602-6.doi:10.2169/internalmedicine.33.602.

23. Takayanagi R, Miura K, Nakagawa $H$, Nawata $H$. Epidemiologystudyof adrenal gland disorders in Japan. BiomedPharmacother2000;54(Suppl 1):164-8.doi:10.1016/s0753-3322(00)80036-0.

24. Hannon AM, Hunter S, Smith D, et al. Clinical featuresandautoimmune associations in patients presenting withldiopathiclsolated ACTH deficiency. Clin Endocrinol(Oxf)2018;88(39:491-7. doi:10.1111/cen.13536.

25. Yamamoto T, Kamoi K. Prevalence of maturity-onset isolatedACTHdeficiency (IAD) in 2005: Japanese cohort studies.EndocrJ 2008;55(5):939-41.doi:10.1507/endocrj.k08e-146.

26. Grinspoon SK, Biller BMK. Clinical review 62:Laboratoryassessment of adrenal insufficiency. $J$ ClinEndocrino/Metab 1994;79(4):923-31.doi:10.1210/jcem.79.4.7962298.

27. Arlt W. The approach to the adult with newly diagnosedadrenalinsufficiency. J Clin Endocrinol Metab2009;94(4):1059-67.doi:10.1210/jc.2009-0032.

28. Artavia-Loria E, Chaussain JL, Bougnères PF, Job JC.Frequencyof hypoglycaemia in children with adrenal insufficiency.ActaEndocrinol Suppl (Copenh)1986;279:275-8.doi:10.1530/acta.0.112s275.

29. Burke CW. Adrenocortical insufficiency. ClinEndocrino/Metab1985;14(4):947-76.doi:10.1016/s0300595x(85)80084-0.

30. Stacpoole PW, Interlandi JW, Nicholson WE, Rabin D.IsolatedACTH deficiency: a heterogeneous disorder.Medicine(Baltimore) 1982;61(1):13-24.

31. Nerup J. Addison's disease--clinical studies. A report of108cases. Acta Endocrinol (Copenh)1974;76(1):127-41.doi:10.1530/acta.0.0760127.

32. Yamamoto T, Fukuyama J, Hasegawa K, et al.Isolatedcorticotropin deficiency in adults. Report of 10 cases andreviewof literature. Arch Intern Med1992;152(8):1705-

12.doi:10.1001/archinte.1992.00400200131024.

33. Sheehan HL. Simmonds's disease due to post-partum necrosisofthe anterior pituitary. QJM1939;8(4):277-309.doi:10.1093/oxfordjournals.qjmed.a069138.

34. Randeva HS, Schoebel J, Byrne J, Esiri M, Adams CB, WassJA.Classical pituitary apoplexy: clinical features, managementandoutcome. Clin Endocrinol (Oxf)1999;51(2):181-8.doi:10.1046/j.13652265.1999.00754.x.

35. Dubuisson AS, Beckers A, Stevenaert A. Classicalpituitarytumour apoplexy: clinical features, management andoutcomes in aseries of 24 patients. Clin Neuro/Neurosurg2007;109(1):637.doi:10.1016/j.clineuro.2006.01.006.

36. Schlaghecke R, Kornely E, Santen RT, Ridderskamp P. Theeffectof long-term glucocorticoid therapy on pituitary-adrenalresponsesto exogenous corticotropin-releasing hormone. $N$ Engl JMed1 992;326(4):226-30. doi:10.1056/NEJM199201233260403. 
37. Sacre K, Dehoux M, Chauveheid MP, et al.Pituitary-adrenalfunction after prolonged glucocorticoid therapyfor systematicinflammatory disorders: an observational study. JClinEndocrinol Metab2013;98(8):3199-205.doi:10.1210/jc.2013-1394.

38. Gonzalez-Moles MA, Scully C. HPA-suppressive effects of aqueousclobetasol propionate in the treatment of patients with orallichenplanus. J Eur Acad Dermatol Venereo/2010;24(9):10559.doi:10.1111/j.1468-3083.2010.03591.x.

39. Habib G, Khazin F, Jabbour A, et al. Simultaneous bilateralkneeinjection of methylprednisolone acetate andthehypothalamic-pituitary adrenal axis: a single-blindcase-controlstudy. J Investig Med2014;62(3):621-6.doi:10.231/JIM.

40. Chanson P, Guignat L, Goichot B, et al. Group 2:Adrenalinsufficiency: screening methods and confirmation ofdiagnosis.Ann Endocrinol (Paris)2017;78(6):495-

511.doi:10.1016/j.ando.2017.10.005.

41. Grossman AB. Clinical Review: The diagnosis and managementofcentral hypoadrenalism. J Clin EndocrinolMetab2010;95(11):4855-63. doi:10.1210/jc.2010-0982.

42. Bornstein SR, Allolio B, Arlt W, et al. Diagnosis andTreatmentof Primary Adrenal Insufficiency: An Endocrine SocietyClinicaIPractice Guideline. J Clin EndocrinolMetab2016;101(2):364-89. doi: 10.1210/jc.2015-1710.

43. Oelkers W, Diederich S, Bähr V. Diagnosis andtherapysurveillance in Addison's disease: rapid adrenocorticotropin(ACTH)test and measurement of plasma ACTH, renin activity,andaldosterone. $J$ Clin Endocrinol Metab1992;75(1):259-64.doi:10.1210/jcem.75.1.1320051.

44. Andrioli M, Giraldi FP, Cavagnini F. Isolatedcorticotrophindeficiency. Pituitary2006;9:28995.doi:10.1007/s11102-006-0408-5.

45. Hannon MJ, O'Halloran DJ. Isolated acquired ACTH deficiencyandprimary hypothyroidism: a short series andreview. Pituitary2011;14:358-61.doi:10.1007/s11102-008-0164-9.

46. Krasner AS. Glucocorticoid-induced adrenalinsufficiency.JAMA 1999;282(7):6716.doi:10.1001/jama.282.7.671.

47. Dorin RI, Qualls CR, Crapo LM. Diagnosis ofadrenalinsufficiency. Ann Intern Med2003;139(3):194204.doi:10.7326/0003-4819-139-3-200308050-00009.

48. Ospina NS, Nofal AA, Bancos I, et al. ACTH stimulating testsforthe diagnosis of adrenal insufficiency: systematic reviewandmeta-analysis. J Clin Endocrinol Metab2016;101(2):42734.doi:10.1210/jc.2015-1700.

\section{Tables}

Table1. Baseline characteristics of the 34patients who were newly diagnosed with adrenalinsufficiency ${ }^{\mathrm{a}}$. 


\begin{tabular}{|c|c|}
\hline Characteristics & $\begin{array}{c}\text { Total } \\
(\mathrm{n}=34)\end{array}$ \\
\hline Mean ageat diagnosis, year (SD) & $76.3(14.1)$ \\
\hline Femalesex & $11(32.4)$ \\
\hline \multicolumn{2}{|l|}{ Pastmedical history } \\
\hline Pituitary tumour & $1(2.9)$ \\
\hline Head trauma & $4(11.8)$ \\
\hline Autoimmune thyroid disease & $1(2.9)$ \\
\hline Rheumatological disease & $7(20.6)$ \\
\hline Major depressive disorder & $1(2.9)$ \\
\hline Mean timeto diagnosis from onset, months (SD) & $6.2(10.3)$ \\
\hline Current orformer use of glucocorticoids for non-endocrinedisease & $11(32.4)$ \\
\hline Pigmentation & $1(2.9)$ \\
\hline \multicolumn{2}{|l|}{ Laboratoryfindings at diagnosis } \\
\hline White blood cell count (SD) & $7200(2800)$ \\
\hline Eosinophil cell count (SD) & $313(352)$ \\
\hline Serumsodium, mEq/dl (SD) & $134(12)$ \\
\hline Serum potassium, mEq/dl (SD) & $4.3(0.8)$ \\
\hline Serum glucose, mg/dl (SD) & $110(62)$ \\
\hline Hyponatremia due to SIADH atdiagnosis & $9(26.5)$ \\
\hline Morningserum cortisol, $\mu \mathrm{g} / \mathrm{dl}$ (SD) & $4.1(3.4)$ \\
\hline Morningplasma ACTH, pg/ml (SD) & $15.0(10.7)$ \\
\hline \multicolumn{2}{|l|}{ Standarddose short synacthen test } \\
\hline Serum cortisol at baseline, $\mu \mathrm{g} / \mathrm{dl}(\mathrm{SD})$ & $5.1(4.3)$ \\
\hline Serum cortisol at $30 \mathrm{~min}, \mu \mathrm{g} / \mathrm{dl}$ (SD) & $9.9(4.4)$ \\
\hline Serum cortisol at $60 \mathrm{~min}, \mu \mathrm{g} / \mathrm{dl}$ (SD) & $11.2(4.7)$ \\
\hline \multicolumn{2}{|l|}{ Culpritlesion causing adrenal insufficiency } \\
\hline Primary adrenal insufficiency & $0(0.0)$ \\
\hline Central adrenalinsufficiency & \\
\hline Pituitary & $13(38.2)$ \\
\hline Hypothalamic & $16(47.1)$ \\
\hline Unspecified & $5(14.7)$ \\
\hline \multicolumn{2}{|l|}{ Aetiologyof adrenal insufficiency } \\
\hline Glucocorticoids & $11(32.4)$ \\
\hline Unspecified or unknown cause & $9(26.5)$ \\
\hline Isolated ACTH deficiency & $6(17.7)$ \\
\hline Pituitary tumour or cyst & $5(14.7)$ \\
\hline Meningoencephalitis & $1(2.9)$ \\
\hline Giant cerebral aneurysm & $1(2.9)$ \\
\hline IgG4-associated disease & $1(2.9)$ \\
\hline
\end{tabular}

aValues are expressed as thenumber with the percentage of the total number, unless otherwisestated. ACTH: adrenocorticotropichormone; SD: standard deviation; SIADH: syndrome ofinappropriate secretion of antidiuretic hormone.

Table2. Comparison of clinicalfeatures between glucocorticoid-induced adrenal insufficiency andcentral adrenal insufficiency due to othercauses ${ }^{\mathrm{a}}$. 


\begin{tabular}{|c|c|c|c|}
\hline$\overline{C S}$ & $\begin{array}{c}\text { Drug-induced } \\
\text { AI } \\
(\mathrm{n}=11)\end{array}$ & $\begin{array}{c}\text { Central AI(excluding drug-induced } \\
\qquad \begin{array}{c}\mathrm{AI}) \\
(\mathrm{n}=23)\end{array}\end{array}$ & $\begin{array}{c}P_{-} \\
\text {value }^{\mathrm{b}}\end{array}$ \\
\hline \multirow[t]{2}{*}{ liagnosis, year (SD) } & $75.7(11.5)$ & $76.6(15.4)$ & 0.87 \\
\hline & $4(36.4)$ & $7(30.4)$ & 1.00 \\
\hline \multicolumn{4}{|l|}{ ect diagnosis from onset } \\
\hline is (SD) & $0.9(1.0)$ & $8.8(11.7)$ & 0.03 \\
\hline nonth & $8(72.7)$ & $7(30.4)$ & 0.03 \\
\hline rear & $11(100.0)$ & 17(73.9) & 0.15 \\
\hline of consultations until & $2.2(1.1)$ & $3.6(2.3)$ & 0.06 \\
\hline \multicolumn{4}{|l|}{ ) } \\
\hline \multicolumn{4}{|l|}{ diagnosis } \\
\hline & $8(72.7)$ & $18(78.3)$ & 1.00 \\
\hline \multirow[t]{2}{*}{.alaise } & $3(27.3)$ & $20(87.0)$ & 0.001 \\
\hline & $3(27.3)$ & $19(82.6)$ & 0.01 \\
\hline omiting & $7(63.6)$ & $12(52.2)$ & 0.71 \\
\hline \multirow[t]{6}{*}{ tal status } & $3(27.3)$ & $6(26.1)$ & 1.00 \\
\hline & $4(36.4)$ & $4(17.4)$ & 0.39 \\
\hline & $3(27.3)$ & $5(21.7)$ & 1.00 \\
\hline & $2(18.2)$ & $5(21.7)$ & 1.00 \\
\hline & $3(27.3)$ & $2(8.7)$ & 0.30 \\
\hline & $2(18.2)$ & $2(8.7)$ & 0.58 \\
\hline \multirow[t]{3}{*}{ Iain } & $1(9.1)$ & $3(13.0)$ & 1.00 \\
\hline & $0(0.0)$ & $3(13.0)$ & 0.53 \\
\hline & $2(18.2)$ & $0(0.0)$ & 0.10 \\
\hline \multicolumn{4}{|l|}{ diagnosis } \\
\hline ver episode & $2(18.2)$ & $3(13.0)$ & 1.00 \\
\hline rpotension episode & $3(27.3)$ & $2(8.7)$ & 0.30 \\
\hline \multirow{2}{*}{ nic episode ${ }^{c}$} & $0(0.0)$ & $3(13.0)$ & 0.53 \\
\hline & $1(9.1)$ & $0(0.0)$ & 0.32 \\
\hline \multicolumn{4}{|l|}{ ıdings at diagnosis } \\
\hline cell count (SD) & $7900(3800)$ & $6900(2300)$ & 0.34 \\
\hline cell count (SD) & $392(455)$ & $272(290)$ & 0.40 \\
\hline ium, mEq/dl (SD) & $139(4)$ & $132(13)$ & 0.12 \\
\hline ssium, mEq/dl (SD) & $3.9(0.6)$ & $4.5(0.8)$ & 0.04 \\
\hline sse, mg/dl (SD) & $153(90)$ & $90(26)$ & 0.003 \\
\hline a due to SIADH atdiagnosis & $0(0.0)$ & $9(39.1)$ & 0.02 \\
\hline
\end{tabular}

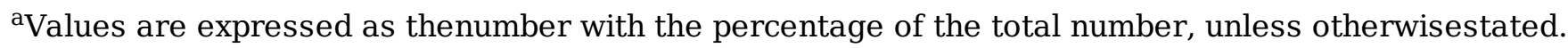

${ }^{\mathrm{b}}$ Comparisons of clinicalfeatures between patients who werediagnosed with glucocorticoid-induced AI and central AIdue to other causes were performed by using Fisher's exact test forcategorical variables and Student's t-test for continuousvariables.

${ }^{\mathrm{C} O n l y}$ symptomatichypoglycaemic episodes that needed intervention wereincluded.

$\mathrm{AI}$ :adrenal insufficiency; ACTH: adrenocorticotropic hormone; SD:standard deviation; SIADH: syndrome of inappropriate secretion ofantidiuretic hormone.

\section{Additional File Legends}

Table S1. Disease lists corresponding toadrenal insufficiency and reasons for exclusions. ${ }^{a}$ Ofthose, 9 cases were diagnosed for the same patients. Thus, a totalof 47 cases were newly diagnosed as adrenal insufficiency andtreated by hormone replacement during the study period. 
Table S2. Baseline characteristics of the 34patients who were newly diagnosed with adrenal insufficiency. ${ }^{a}$ Values are expressed as the number with the percentageof the total number, unless otherwise stated. ${ }^{\text {b}}$ Onlysymptomatic hypoglycaemic episodes that needed intervention wereincluded.

Table S3. Results of tests for thehypothalamic-pituitary-adrenal axis and other hormones in the 34adrenal

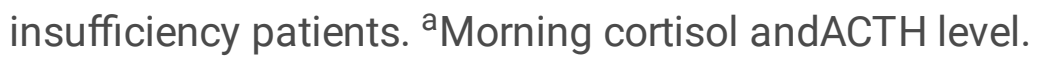

${ }^{b}$ Plus indicates the presence of a response of thetarget organ in the hormone-stimulating tests, while minusindicates no response of the target organ in thehormone-stimulating tests. ${ }^{c}$ Random cortisol level.

\section{Figures}

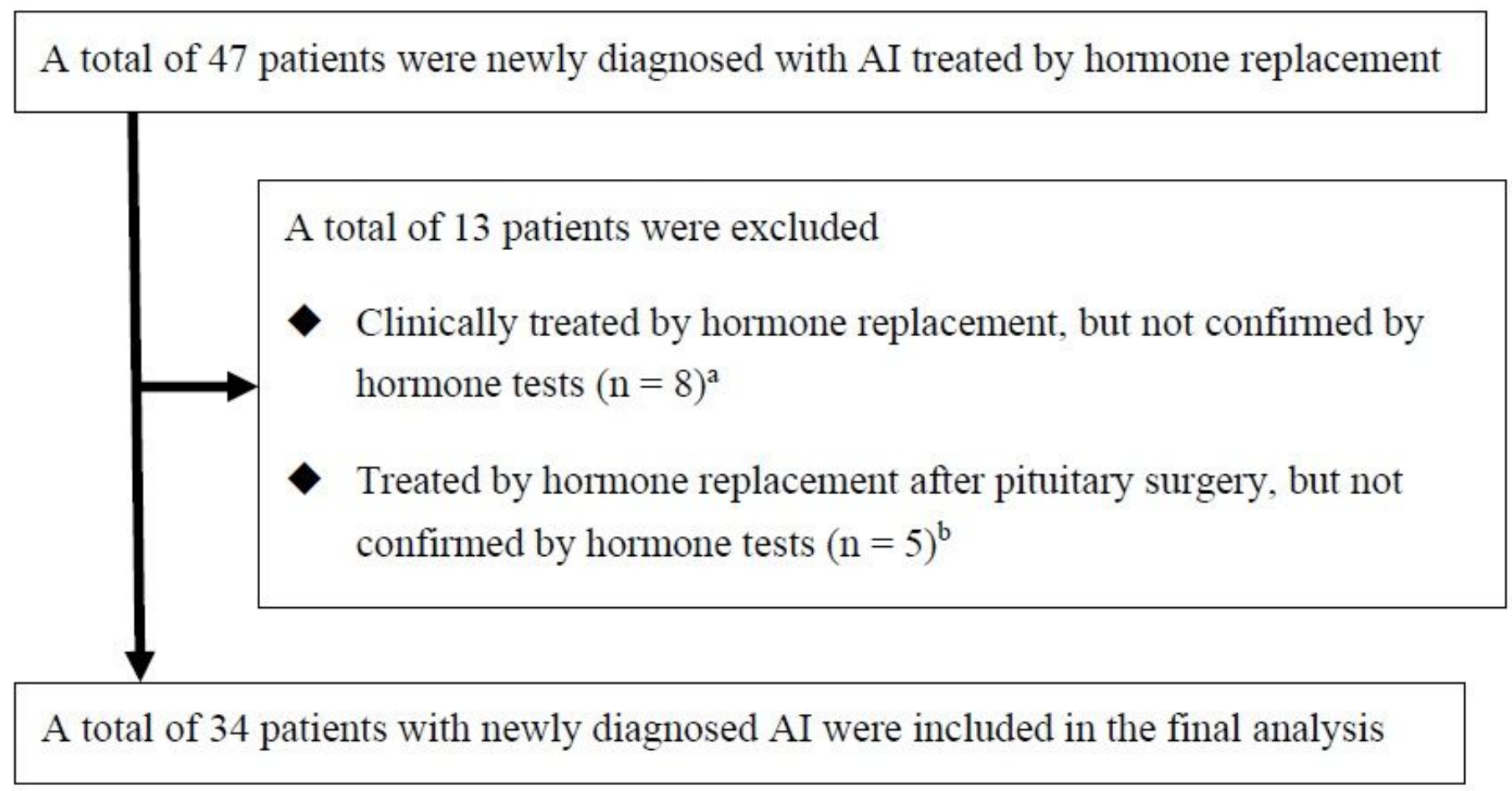

\section{Figure 1}

Flow chart of the 34 patients included in this study. aFive had glucocorticoid-induced adrenal insufficiency or critical illness-related corticosteroid insufficiency, and three had central adrenal insufficiency of unknown causes. bAll patients lacked symptoms associated with adrenal insufficiency. Al: adrenal insufficiency.

\section{Supplementary Files}

This is a list of supplementary files associated with this preprint. Click to download. 
- BMCadrenalinsufficiencyadditionalfile200214.pdf

Page 16/16 